\title{
The use of citric acid in the production of polyols for rigid PUR-PIR foams
}

\author{
Joanna Liszkowska ${ }^{1}$
}

Received: 28 January 2016/Revised: 5 April 2016/Accepted: 19 May 2016/

Published online: 20 June 2016

(C) The Author(s) 2016. This article is published with open access at Springerlink.com

\begin{abstract}
The article describes the method of obtaining new, cheaper compounds which can substitute polyols in the production of rigid polyurethane-polyisocyanurate foams (PUR-PIR). Rigid PUR-PIR foams were synthesized, using newly obtained tree compounds (citrates with hydroxyl groups): obtained with using catalyst $(\mathrm{T}-2-\mathrm{HHT}+\mathrm{K})$, without catalyst $(\mathrm{T}-2-\mathrm{HHT})$ and (T-5-HHT). New compounds (T-2-HHT $+\mathrm{K}, \mathrm{T}-2-\mathrm{HHT}, \mathrm{T}-5-\mathrm{HHT})$ were prepared from citric acid $(1 \mathrm{~mol})$ and glycols, respectively: butane-1.2-diol $\left(3 \mathrm{~mol}\right.$ and excess of $\left.30 \mathrm{~cm}^{3}\right)$, butane-1.2-diol $(3 \mathrm{~mol})$, pentane-1.5-diol $(3 \mathrm{~mol})$ by the esterification reaction in the solution. The industrial Rocopol 551, used as polyol, was gradually substituted for the new compounds in the polyol premix in new foams. The three series of rigid polyurethane-polyisocyanurate foams based on T-2-HHT + K, T-2-HHT, T-5-HHT have been synthesized (F1-F16) and $\mathrm{W}$ foam without new compound. Its properties have been determined according to the standards. It has been shown that the addition of T-2-HHT $+\mathrm{K}$, T-2-HHT, T-5-HHT to the foams affects the foams' density. The influence of the abovementioned compounds on foams' flammability, thermal properties and others was examined. A decrease in foams' brittleness by $6.9 \%$ and in oxygen index by $24 \%$ was observed. The examined retention was in the range of $80.9-96.5 \%$.
\end{abstract}

Keywords Citric acid · Propane-1.2-diol · Pentane-1.2-diol ·

Polyurethane-polyisocyanurate foam $\cdot$ Esterification

Joanna Liszkowska

liszk@ukw.edu.pl

1 Chair of Chemistry and Technology of Polyurethanes, Kazimierz Wielki University in Bydgoszcz, Chodkiewicza str. 30, 85-064 Bydgoszcz, Poland 


\section{Introduction}

Polyurethanes are based on two components, an isocyanate component and a diol component. The diol component can be a polyether end-capped diol or a polyester end-capped diol. Among polyesterols, Fink [1] distinguishes such types as: grafted polyols, polyurea-modified polyols, autocatalytic polyols. He also believes that polyetherols can be used in flexible foams, semi-rigid foams, rigid foams or elastomers, depending on the carboxyl acids used for their synthesis. Carboxylic acids, or their derivatives, terephthalic acid, adipic acid or glycols (mainly diethylene and propylene), are used for the production of polyetherols. The type of polyol has an effect on all of the polyurethane's properties. Czupryński [2] believes that oligoesterols with $300-450 \mathrm{mg} \mathrm{KOH} / \mathrm{g}$ acid number and water content below $1 \%$ are the most beneficial for the use in rigid foams. Based on the conducted research, Czupryński obtained foams with very good application properties (thermal, durability, and others). The use of aromatic oligomerols increases foams' durability. Oligoetherols increase foams' flexibility and, therefore, decrease their brittleness. Landrock [3] writes that the polyols for urethane foams include polyether polyols, polyester polyols, hydroxyl-terminated polyolefins and hydroxylcontaining vegetable oils. The hydroxyl numbers of polyols increase from flexible foams to rigid foams from $60 \mathrm{mg} \mathrm{KOH} / \mathrm{g}$ up to $400 \mathrm{mg} \mathrm{KOH} / \mathrm{g}$. Acids for soft foams are aliphatic acids (adipic), but phthalic anhydride increases the rigidity. Oligomerols are compounds having a molecular weight 1000-6000 (oligoetherols) add 2000 (oligoesterols) [4]. The molecular mass of the oligoetherol has a more pronounced effect on the $\mathrm{OH}$ group reactivity than the molecular mass of oligoesterol. Polyetherols are synthesized from azacyclic compounds and oxiranes [5-7].

PUR foams are flammable materials. When burnt, harmful volatile substances are produced which sustain the burning and help spread the fire. Therefore, there is a need to use different types of methods which would help decrease the flammability. One of such methods is a synthesis of special polyols (or polyol premix) containing particles of chlorine, bromine, boron, nitrogen and others. Paciorek-Sadowska et al. $[8,9]$ used the derivatives of boric acid to lower foams' flammability. The obtained borates, added to the rigid foams, elongated their combustion time and shown a foam cooling effect. Polyol premix for the production of ecological rigid polyurethane foam with decreased flammability, containing dibromobutanediol as a reactive antipirene is the subject of Brzozowski et al. [10]. Those were the foams, foamed with pentane. The oxygen index of the foams foamed with pentane has not exceeded $20 \%$ up until now. Brzozowski added a combination of two reactive antipirenes with functional hydroxyl groups, one of which contained bromine mixed with aliphatic carbon atom and the second one contained bromine mixed with aromatic carbon atom and additive antipirene. This solution resulted in obtaining oxygen index in the range of 24-27\%. Often decreasing flammability of polyols are complimented or substituted by other antipirenes. Nanofillers are the latest trend. Nanofillers based on silica limit the flow of heat into the polymer's core, increasing its heat resistance [11]. Nanofillers based on silica which has been modified with 
phosphorous compound do not contain halogen atoms, which makes them environmentally friendly. During the burning process, they do not produce halogens and other compounds which are toxic. Besides that, they enable low composition filling (1-10\% mass.). Additionally, they limit the amount of volatile substances produced and lower the flammability of materials by creating a protective layer on their surface, which limits the flow of heat and oxygen into the material's core. Products of glycolysis, hydrolysis and aminolysis are used. Zia et al. [12] think that increasing waste-to-energy and other thermal processing activities involving gasification, pyrolysis and two-stage combustion has contributed for the disposal of significant amounts of scrap PU without many difficulties. It is concluded that many of the plastic feedstock recycling processes appear to be technically feasible and robust enough to warrant further development in the future. For instance, the glycolysis products obtained from rigid PU foam, known as secondary polyols, maybe useable as hydroxyl-containing components in secondary PU synthesis, including foams, sealants and adhesives. In hydroglycolysis the recovered polyol may replace up to $50 \%$ of virgin polyol material for polyurethane foams. Pielichowski et al. [13] synthesized rigid foams from with recycled waste foamed polyurethanes, polystyrene or suspension poly(vinyl chloride). The presented polymer waste management and utilization process allows for a decrease in the consumption of virgin materials and volatile amine catalysts. Czupryński et al. [14-16] surrendered glycolysis of PUR-PIR rigid foam. Then, from the resulting glycolysis product he obtained new rigid foam, with superior strength and reduced brittleness.

Spychaj and Kacperski [17] obtained reactive mixture produced as a result of the degradation of phthalic or terephthalic acids. The obtained products had high viscosity and limited stability when stored. Oxyalkylation and complete distillation of volatile by-products was necessary, which increased the price of those processes. The products were used for the synthesis of rigid foams with lowered flammability. Foams' lowered flammability was a result of the presence of III-tier nitrogen in the foams' chain, which came from diethanolamine and triethanolamine, used in the PET decomposition.

Other polyol types are polyols coming from renewable raw materials. Polyols from vegetable oils were produced by Prociak [18-20], Pawlik and Prociak [21], Kurańska and Prociak [22]. He used glycerin, containing three hydroxyl groups, for the synthesis of polyols with vegetable oils to increase their hydroxyl number. The use of glycerin was intentional from the technical, economic and ecological points of view. The obtained polyols were used for the synthesis of thermos-insulating rigid foams. They had improved viscosity and hydroxyl number. They were characterized by good durability and thermo-insulation properties.

Based on various polyols, different types of rigid foams (polyurethane, polyisocyanurate, others), flexible foams, elastomers, glues, insulations were produced by Wirpsza [4] and Kurańska and Prociak [23]. However, the production of PU from the abovementioned raw materials affects the foam price. One of the less expensive carboxylic acids on the market is the citric acid. It is mostly known as a material used in the food industry obtained by Soccol et al. [24] and Vandenberghe et al. [25] or as well as the detergent industry examined by Grewal 
and Karla [26] and Pandey at al. [27] and Tisserat et al. [28]. It is not widely used in the chemistry of polymers, so far used to producing polyesters by Tisserat et al. [28]. Citric acid is the cheapest carboxylic acid available on the market. During reaction of this acid with glycols, new compounds with hydroxyl groups are created that can be subjected to further synthesis what was described by Holster [29]. Compounds for further production of rigid polyurethane-polyisocyanurate foams using citric acid were conducted only with the use of selected glycols (butane-1,4diol, butane-1,3-diol, diethylene glycol).

Liszkowska et al. [30, 31] used glycols to spread various foam-filled fillers. Starting materials and fillers (added for primary foam) which are not separated were obtained as a result of glycolysis. Using glycolysis a new foam having higher compression strength and lower brittleness than the primary foam was obtained.

Rigid foams with thermally stable properties were obtained by Zarzyka [32]. She obtained hydroxyalkyl derivatives containing oxamidoester and oxamide fragments. She used oxamic acid, oxamide and alkylene carbonates. The presence of oxamidoester and oxamide structural fragments in oligomer structures is responsible for the thermal stability of these products used as polyols for rigid, polyurethane foams. The polyurethane foams characterized by the best properties were obtained from hydroxypropyl derivatives of oxamide. Until now, polyols were obtained from citrate acid based on such glycols as butanediol, diethylene glycol [33, 34].

Nanocomposites of waterborne polyurethane (WPU) reinforced with functionalized graphene sheets (FGSs) were synthesized by Choi et al. [35]. Due to finely dispersed FGS, nanocomposites with enhanced electrical conductivity and thermal resistance were received. FGS deteriorated tensile strength and elongation at break, because of difficult rearrangement the chain in the nanocomposite.

A series of novel linear segmented polyurethanes (PUs) containing a pyridine unit in the main chain have been synthesized by polycondensation reaction of various diisocyanates, 4,4'-diphenyl-methane diisocyanate (MDI), toluene 2,4diisocyanate (TDI), isophorone diisocyanate (IPDI) and hexamethylene diisocyanate (HDI), with 4,4'-\{pyridine-2,6-diylbis[nitrilomethylylidene]\}diphenolbased diol [36]. All the examined PUs were soluble in polar aprotic solvents. MDI-based PU show more thermal stability compared to other PUs [37].

This article presents the continuation of research from previous years. Synthesis of other, new materials for rigid foam production was conducted: $\mathrm{T}-2-\mathrm{HHT}+\mathrm{K}$, T-2-HHT and T-5-HHT. Obtained compounds containing reactive hydroxyl groups were synthesized from citric acid and propane-1.2-diol or pentane-1.5-diol. Selecting reaction parameters, so that the obtained compounds would be useful for foam synthesis, was the aim of the research. Their influence on the physicomechanical and physicochemical properties of PUR-PIR foams was assessed. The addition of the obtained ester derivatives causes an increase in flexible bonds in PUR-PIR chain, thus decreasing the foam's brittleness. 


\section{Experimental}

\section{Materials}

Polyester with trade name Rocopol RF 551 poly(oxypropylene)diol with hydroxyl number $420 \mathrm{mg} \mathrm{KOH} / \mathrm{g}$, molecular weight $=660$ ) product of Chemical Plants PCC Rokita S.A. in Brzeg Dolny was used to prepare rigid PUR-PIR foams. As a crossing compound used technical polymeric diisocyanate Ongromat 30-20 (BorsodChem, Hungary), whose main component is 4,4'-diphenyl-methane-diisocyanate (MDI). Density of Ongromat 30-20 at temperature of $25{ }^{\circ} \mathrm{C}$ was $1.23 \mathrm{~g} / \mathrm{cm}^{3}$, viscosity was $200 \mathrm{mPa} \mathrm{s}$, and content of NCO groups was $31.0 \%$. Polyether and diisocyanate were characterized according to standards: ASTM D 2849-69 and ASTM D 1638-70. Catalyst in the process of foam preparation was anhydrous potassium acetate (POCh Gliwice) applied in the form of $33 \%$ solution in diethylene glycol (catalyst 12) and DABCO 33LV (diazobicyclooctan in triethylenediamine, Hülls, Germany) used as $33 \%$ solution in diethylene glycol. Stabilizer of foam structure was poly(oxyalkilene siloxane) surfaceactive agent Tegostab 8460 (Witco, Sweden). Carbon dioxide formed in reaction of water with isocyanate groups acted as blowing agent. Moreover, liquid flame retardant tris-(2chloropropyl)phosphate-Roflam P (Albright and Wilson, Great Britain) was introduced into foam composition. For synthesis of preparation of Catalyst 12 diethylene glycol, POCH Gliwice, was used. Lewis acid - tetraisopropyl titanate was applied as catalyst in synthesis of new compound T-2-HHT + K, T-2-HHT, T-5-HHT. Trade name of the catalyst is Tyzor TPT (Du Pont). It is colorless, yellowish liquid with freezing temperature of $19{ }^{\circ} \mathrm{C}$, highly sensitive to moisture. The characteristic is as follows: content of $\mathrm{TiO}_{2}, 28.1 \%$; molecular mass, $284 \mathrm{~g} / \mathrm{mole}$; density at $20{ }^{\circ} \mathrm{C}, 0.95 \mathrm{~g} / \mathrm{cm}^{3}$; viscosity, $3.5 \mathrm{mPa} \mathrm{s}$; boiling point, $232{ }^{\circ} \mathrm{C}$; miscible in majority of organic solvents, easily soluble in water. For synthesis of new three compounds used 2-hydroxypropane1.2.3-tricarboxylic acid (citric), Brenntag Poland LLC company in Kędzierzyn Koźle and propane-1.2-diol and pentane-1.5-diol (POCh Gliwice). Three new compounds (produced in the Department of Chemistry and Technology of Polyurethanes, Kazimierz Wielki University in Bydgoszcz, Poland) containing hydroxyl groups (called T-2HHT + K, T-2-HHT, T-5-HHT) were used in the synthesis of PUR-PIR foams.

\section{Synthesis of new compounds T-2-HHT + K, T-2-HHT, T-5-HHT}

Compounds named T-2-HHT $+\mathrm{K}, \mathrm{T}-2-\mathrm{HHT}$, T-5-HHT were synthesized by solvent method (in xylene). It was assumed that the reactions proceed according to the general Scheme 1. First (T-2-HHT $+\mathrm{K})$ was synthesized in the reaction of 2-hydroxypropane-1.2.3-tricarboxylic acid (citric)—96 $\mathrm{g}$ and propane-1.2-diol $(144 \mathrm{~g})$ in the presence of $0.01 \%(0.024 \mathrm{~g})$ of catalyst (Tyzor TPT). Second (T2-HHT) product was obtained using $96 \mathrm{~g}$ of citric acid and $114 \mathrm{~g}$ of propane-1.2diol. Compound T-5-HHT was obtained by mixing $96 \mathrm{~g}$ of 2-hydroxypropane-1.2.3tricarboxylic acid (citric) with $156 \mathrm{~g}$ of pentane-1.5-diol; $0.04 \%$ (0.096 g) titanate isobutyl (Tyzor TPT) was used as catalyst 


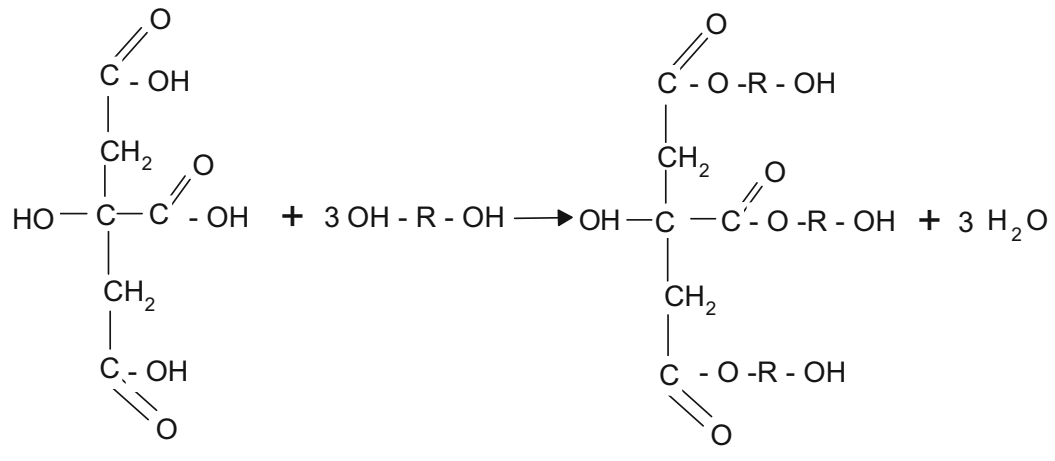

citric acid diol citrate water

where R: $-\mathrm{CH}_{2}-\mathrm{CH}-\mathrm{CH}_{3}$ or $-\left(\mathrm{CH}_{2}\right)_{5}-$.

Synthesis was conducted in three-neck glass flask $\left(500 \mathrm{~cm}^{3}\right.$ vol. each) equipped with reflux condenser, thermometer, stirrer and Dean-Stark head. The generated water was collected in the head. Flask was heated in an electric bath. Synthesis 1 took $6 \mathrm{~h}$, synthesis 2 took $9.5 \mathrm{~h}$ and synthesis 3 took $5 \mathrm{~h}$. The temperature of the reaction 1 was $155^{\circ} \mathrm{C}$ at beginning and $143{ }^{\circ} \mathrm{C}$ at the end of process, of reaction 2 the temperature was $154{ }^{\circ} \mathrm{C}$, of reaction 3 the temperature was $161{ }^{\circ} \mathrm{C}$.

\section{Determination of properties of the T-2-HHT + K, T-2-HHT, T-5-HHT products}

After synthesis the obtained products (T-2-HHT $+\mathrm{K}, \mathrm{T}-2-\mathrm{HHT}, \mathrm{T}-5-\mathrm{HHT})$ was cooled and analyzed. The following parameters were determined: hydroxyl number (PN-93/C-89052.03), viscosity (PN-86/C-98082.04, Hoeppler viscosimeter), density (PN-92/C-04504), water content (PN-81/C-04959, by Carl Fisher's method), pH (microcomputer $\mathrm{pH}$-meter $\mathrm{CP}-551$ ).

\section{Synthesis of the rigid PUR-PIR foams}

The foam was prepared in a laboratory scale by one-stage method from the twocomponent system at the equivalent relation of $-\mathrm{NCO}$ to $\mathrm{OH}$ groups equal to $3: 1$. The component A was obtained by the precise mixing (1800 rpm, $10 \mathrm{~s}$ ) of the suitable amounts of Rocopol RF 551 from 1R (66.8 g) to 0.5R (33.4 g), catalyst 12 (6.7 g), catalyst DABCO (2.9 g), antipirene Roflam P (47.6 g), surface-active agent Silicone Tegostab 8460 (54.7 g), porophor (3.15-3.11 g of distilled water). Component B was polyisocyanate Ongromat 30-20 in amount of $250.7 \mathrm{~g}$. The amount of isocyanate was chosen based on the ratio of isocyanate groups to hydroxyl groups, which for the rigid polyurethane-polyisocyanate foams was 3:1. The calculated amount of isocyanate was expanded by the mass of isocyanate 
necessary for the reaction with water. As a result of the reaction, a gas which foams the reactive mixture is produced $-\mathrm{CO}_{2}$. The isocyanate group chemical equivalent $(R)$ was calculated according to the following equation:

$$
R=\frac{4200}{31 \% \mathrm{NCO}},
$$

where \% NCO stands for the content of NCO group in polyisocyanate.

The hydroxyl group chemical equivalent $(R)$ was calculated according to the following equation:

$$
R=\frac{56,100}{\mathrm{HN}}
$$

in which $\mathrm{HN}$-hydroxyl number of obtained product (T-2-HHT $+\mathrm{K}, \mathrm{T}-2-\mathrm{HHT}$ or T-5-HHT)

Products (T-2-HHT + K, T-2-HHT, T-5-HHT) were added in amount from $0.1 \mathrm{R}$ (chemical equivalent) to $0.5 \mathrm{R}$ (Table 1 ). T-2-HHT $+\mathrm{K}$ and $\mathrm{T}-5$-HHT were added in $20{ }^{\circ} \mathrm{C}$ (they were liquid) but T-2-HHT was added after heating to $55^{\circ} \mathrm{C}$ (because of its high viscosity, not possible to examine at $25^{\circ} \mathrm{C}$ ). Both components were mixed $(1800 \mathrm{rpm}, 10 \mathrm{~s})$ at respective volume ratio and poured onto an open rectangular tray of internal dimensions $190 \times 190 \times 230(\mathrm{~mm})$. Series F1-F15 and $\mathrm{W}$ of foams were obtained.

Table 1 Components of F14F16 series of foam (W-reference

\begin{tabular}{|c|c|c|c|c|c|c|c|c|}
\hline \multirow[t]{3}{*}{ Foam } & \multicolumn{8}{|c|}{ Polyol } \\
\hline & \multicolumn{2}{|c|}{ Rokopol } & \multicolumn{2}{|c|}{$\mathrm{T}-2-\mathrm{HHT}+\mathrm{K}$} & \multicolumn{2}{|c|}{ T-2-HHT } & \multicolumn{2}{|c|}{ T-5-HHT } \\
\hline & $\mathrm{R}$ & $\mathrm{g}$ & $\mathrm{R}$ & $\mathrm{g}$ & $\mathrm{R}$ & $\mathrm{g}$ & $\mathrm{R}$ & $\mathrm{g}$ \\
\hline W & 1 & 66.8 & 0 & 0 & 0 & 0 & 0 & 0 \\
\hline F14.1 & 0.9 & 16.1 & 0.1 & 10.8 & - & - & - & - \\
\hline F14.2 & 0.8 & 53.4 & 0.2 & 21.5 & - & - & - & - \\
\hline F14.3 & 0.7 & 46.8 & 0.3 & 32.3 & - & - & - & - \\
\hline F14.4 & 0.6 & 40.1 & 0.4 & 43.1 & - & - & - & - \\
\hline F15.1 & 0.9 & 16.1 & - & - & 0.1 & 9.3 & - & - \\
\hline F15.2 & 0.8 & 53.4 & - & - & 0.2 & 18.6 & - & - \\
\hline F15.3 & 0.7 & 46.8 & - & - & 0.3 & 27.9 & - & - \\
\hline F15.4 & 0.6 & 40.1 & - & - & 0.4 & 37.2 & - & - \\
\hline F16.1 & 0.9 & 16.1 & - & - & - & - & 0.1 & 6.4 \\
\hline F16.2 & 0.8 & 53.4 & - & - & - & - & 0.2 & 12.9 \\
\hline F16.3 & 0.7 & 46.8 & - & - & - & - & 0.3 & 19.3 \\
\hline F16.4 & 0.6 & 40.1 & - & - & - & - & 0.4 & 25.7 \\
\hline F16.5 & 0.5 & 32.2 & - & - & - & - & 0.5 & 33.4 \\
\hline
\end{tabular}
foam) 


\section{Determination of the PUR-PIR foam properties}

The course of the process temperature inside the foam was measured using laboratory thermometer inserted into the center of each of foam. The parameters of processing (start time, growth time and gelation time) were measured during synthesis using a stopwatch. The start time was the time measured from mixing all the components until the so-called "state of cream". This is shown by starting to increase the volume of the foam. The rise time was the time measured by a stopwatch from mixing all components of the foam until the maximum volume of the foam. The gel time was the time measured by a stopwatch from mixing all foam components, until the free surface of the foam stops sticking to a clean glass rod. After expanding, the foam was removed from the tray and thermostated during $4 \mathrm{~h}$ at the temperature of $120{ }^{\circ} \mathrm{C}$. Then, they were seasoned for $48 \mathrm{~h}$ at the temperature of $20 \pm 4{ }^{\circ} \mathrm{C}$ and cut to samples of respective dimensions.

Thermal properties of foams as well as changes in linear, volume and mass dimensions were determined according to ISO 1923:1981 and PN-ISO 4590:1994. The other basic properties were determined according to the obligatory standards: structure of foams-microscope Eclipse $400 \mathrm{POL}$ (Canon, Japan), transmitting light, magnification -4 times; compressive strength using strength machine Tira Test 2200 (ISO 844:1993: DIN 53420); brittleness (ASTM C-421-61); heat resistance (softening point) by Vicat apparatus (DIN 53424); density (ISO 845-1988).

The examination of changes occurring in foams under heat was conducted using differential scanning calorimeter DSC Q200 by TA Instruments with built-in Advanced Tzero technology. The apparatus working range is from -90 to $+725{ }^{\circ} \mathrm{C}$ (foam examinations were conducted in the range from 0 to $400{ }^{\circ} \mathrm{C}$ ).

\section{Results and discussion}

As a result of the synthesis of citric acid with glycols, the following compounds have been obtained: T-2-HHT + K, T-2-HHT, T-5-HHT. The hydroxyl number $(\mathrm{HN})$ is the basic parameter of the oligomerol that is needed to calculate the polyurethane compound recipe. Based on that, the $\mathrm{R}$ equivalent is determined, which corresponds to the amount of compound containing hydroxyl groups (oligomerol) in relation to the amount of remaining foam components, accordingly to the equation: $R=56,100 / L_{\mathrm{OH}}$. That is why the $\mathrm{HN}$ was marked for the new compounds used in the foams (Table 2). The $\mathrm{HN}$ of the obtained products was in the range from $280 \mathrm{mg} \mathrm{KOH} / \mathrm{g}(\mathrm{T}-2-\mathrm{HHT}+\mathrm{K})$ to $436 \mathrm{mg} \mathrm{KOH} / \mathrm{g}$ (T-5-HHT). The value of hydroxyl number is within the range of $L_{\mathrm{OH}}$ of industrial polyols. The hydroxyl number of the examined compounds (above $200 \mathrm{mg} \mathrm{KOH} / \mathrm{g}$ ) indicated that they are an interesting material for the production of rigid PUR-PIR foams. As a result of that, the foaming process of PUR-PIR foams with the addition of the new compound should progress similarly to the synthesis of foams with polyols available on the market.

The analysis of reaction products shows the presence of not-reacted carboxyl groups in them, which is proved by the value of the acid number of the obtained 
Table 2 Basic properties of esterification products

\begin{tabular}{|c|c|c|c|c|c|c|c|}
\hline Compound & $\begin{array}{l}\text { Hydroxyl } \\
\text { number } \\
(\mathrm{mg} \mathrm{KOH} / \mathrm{g})\end{array}$ & $\begin{array}{l}\text { Acid number } \\
(\mathrm{mg} \mathrm{KOH} / \mathrm{g})\end{array}$ & $\begin{array}{l}\text { Content of } \\
\text { water }(\%)\end{array}$ & $\mathrm{pH}$ & Color & $\begin{array}{l}\text { Viscosity at } \\
25^{\circ} \mathrm{C} \\
(\mathrm{mPa} \mathrm{s})\end{array}$ & $\begin{array}{l}\text { Density at } \\
25^{\circ} \mathrm{C}(\mathrm{g} / \\
\left.\mathrm{cm}^{3}\right)\end{array}$ \\
\hline $\begin{array}{r}\text { Rokopol } \\
\text { RF551 }\end{array}$ & 420 & Max. 0.1 & Max. 0.1 & & $\begin{array}{l}\text { Light } \\
\text { yellow }\end{array}$ & 4000 & 1.09 \\
\hline $\begin{array}{l}\text { T-2- } \\
\text { HHT }+ \text { K }\end{array}$ & 280 & 52 & 2.3 & 2.2 & $\begin{array}{l}\text { Straw- } \\
\text { yellow }\end{array}$ & 3972 & 1.200 \\
\hline T-2-HHT & 300 & 23 & 1.2 & 5.5 & $\begin{array}{l}\text { Straw- } \\
\text { yellow }\end{array}$ & $\begin{array}{l}\text { Not } \\
\text { possible } \\
\text { to } \\
\text { measure }\end{array}$ & $\begin{array}{l}\text { Not possible } \\
\text { to } \\
\text { measured }\end{array}$ \\
\hline T-5-HHT & 436 & 43 & 0.98 & 5.1 & $\begin{array}{l}\text { Light } \\
\text { yellow }\end{array}$ & 10364 & 1.053 \\
\hline
\end{tabular}

products (Table 4). At the same time, it was noticed that the amount of distilled water is greater than the expected amount calculated based on the reaction's stoichiometry. This can be a sign of additional esterification reaction of the obtained hydroxyalkyl citrates with the non-reacted carboxyl groups of the neighboring particles. Also, ethers can be created between the hydroxyl group of citric acid and the used glycol. It has been verified that the structure of the obtained products is more complex; one particle can contain multiple structural fragments of citric acid and $\mathrm{O}-\mathrm{R}-\mathrm{O}$ bridges connecting citric acid's particles.

The acid number (AN) of the obtained T-2-HHT $+\mathrm{K}$ product equals $52 \mathrm{mg}$ $\mathrm{KOH} / \mathrm{g}$. This proves that the product contains not-reacted carboxyl groups. Based on the AN value, it is possible to calculate in what mass of the structural fragment is the carboxyl group (Scheme 2):

$$
56,100 / 52=1078.8 \mathrm{~g}
$$

The provided calculations show that it is a much greater mass than the mole mass of the T-2-HHT + K citrate, obtained according to Scheme 1 tri(hydroxyalkyl) (citrate). Based on that, it can be deduced that during the esterification, subsidiary reactions of step-growth polymerization of citric acid and diol particles occur. It is possible to calculate how many particles (moles) of citric acid comprise the composition of the structural fragment containing 1 mol of carboxyl groups (according to Eq. 3). If $x$ marks the number of citric acid moles and it is assumed that water is produced during step-growth polymerization reaction, it can be stated that (Scheme 3):

$$
192 \cdot x+3 \cdot 76 \cdot x-18 \cdot n=1078.8,
$$

where $x$ the number of citric acid moles in a 1078.8-g structural fragment; $n$ the number of moles for the water produced as a result of additional step-growth polymerization or etherification; 192-molecular weight of the molecule of citric acid; 76-molecular weight of the molecule of butane-1.2-diol; 18-molecular 
weight of the molecule of water; 1078.8 - mass of the structural fragment with the carboxyl group.

Assuming that $n$ can equal from 1 to 4 , a value from 2.47 to 2.27 is calculated (assuming $x=2$ ). Based on the value of the hydroxyl number of the obtained product, it can be estimated how many moles of hydroxyl groups $(y)$ are in the analyzed structural fragment (according to Scheme 4).

$$
y=280 \cdot 1078.8 / 56,100=5 \mathrm{~mol} \text { of } \mathrm{OH} \text { group, }
$$

where 280-hydroxyl number of E product.

Knowing, that $2 \mathrm{~mol}$ of citric acid react with $6 \mathrm{~mol}$ of glycol (butane-1.2-diol), and that in the obtained product there is $1 \mathrm{~mol}$ of carboxyl groups and around $5 \mathrm{~mol}$ of hydroxyl groups, an approximate structure of the obtained product can be suggested (Scheme 5)

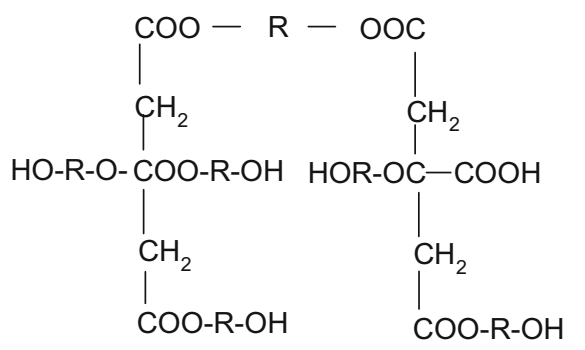<smiles>CCC=[Ru]CCCC</smiles>

The presented scheme indicates that for the reaction of $6 \mathrm{~mol}$ of glycol, an etherification of hydroxyl groups needs to take place in addition to the esterification reaction. 1 not-reacted carboxyl group and 5 hydroxyl groups are present in the obtained structure. It can be calculated that the mole mass of the obtained product equals $750 \mathrm{~g}$. Hence, the acid number equals 56,100/ $750=74.8 \mathrm{mg} \mathrm{KOH} / \mathrm{g}$, while the marked $\mathrm{AN}=52 \mathrm{mg} \mathrm{KOH} / \mathrm{g}$ and hydroxyl number $\mathrm{HN}=5 \times 56,100 / 750=374 \mathrm{mg} \mathrm{KOH}$ and the marked AN equals 280 . Those subtle differences in the calculated values are probably a result of the assumption that $x=3$, while based on the presented calculations $x$ ranged from 2.48 to 2.60 .

Similar calculations were performed for E15 and E16. As for the E15, it showed that around 6 mol of citric acid react with 18 mol of butane-1.2-diol. The estimated amount of $\mathrm{OH}$ groups is 13. Based on that, Scheme 6 was proposed 


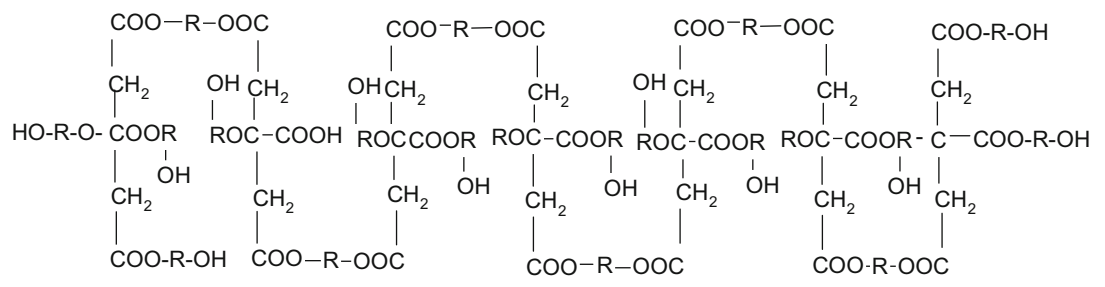

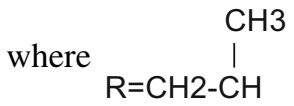

The E16 calculations show that around 3 mol of citric acid react with 9 mol of pentante-1.5-diol. The estimated amount of $\mathrm{OH}$ groups is 10. Based on that Scheme 7 was proposed.

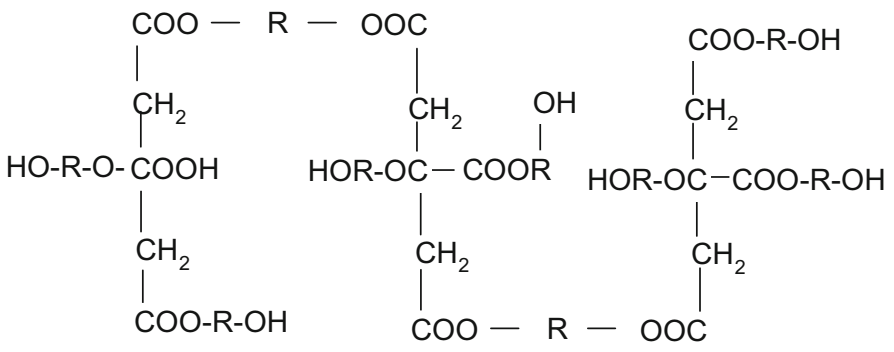

where: $\mathrm{R}=\left(\mathrm{CH}_{2}\right)_{5}$.

The obtained structure (Schemes 5, 6, 7) was confirmed by IR spectrum (Fig. 1) and HNMR spectrum (Fig. 2).

The tremor at $1750 \mathrm{~cm}^{-1}$ wavelength (1) is the $\mathrm{C}=\mathrm{O}$ wave characteristic for aliphatic esters. Moreover, in this spectrum there is a high volume $\mathrm{C}-\mathrm{O}$ bond in the ester (2) at $1190 \mathrm{~cm}^{-1}$ (for T-2-HHT and T-5-HHT) and at $1216 \mathrm{~cm}^{-1}$ (for T-2$\mathrm{HHT}+\mathrm{K}$ ). In the IR spectrum of T-2-HHT $+\mathrm{K}$ and T-2-HHT, there is visible short tremor at around $965 \mathrm{~cm}^{-1}$ (3) coming from OH group present in the carboxyl group (the same group is represented by a tremor at $966 \mathrm{~cm}^{-1}$ for T-5-HHT).The $3300-3600 \mathrm{~cm}^{-1}$ (4) range, is the stretching tremor wave for $\mathrm{O}-\mathrm{H}$ group. In the $1046 \mathrm{~cm}^{-1} \mathrm{C}-\mathrm{O}-\mathrm{C}$ (5) ether wave was observed (for T-2-HHT $+\mathrm{K}$ ) and $1050 \mathrm{~cm}^{-1}$ (for T-2-HHT) and $1040 \mathrm{~cm}^{-1}$ (for T-5-HHT). In the $1117 \mathrm{~cm}^{-1} \mathrm{C}-\mathrm{O}-$ $\mathrm{C}$ ether wave (6) was observed (for T-2-HHT $+\mathrm{K}$ and T-2-HHT) and in $1120 \mathrm{~cm}^{-1}$ (for T-5-HHT).

In the HNMR spectrum there is a visible tremor with $12.3 \mathrm{ppm}$ chemical shift indicating the presence of non-reacted carboxyl group. Hydroxyl groups are represented by a tremor at $5.7 \mathrm{ppm}$, which fades after adding $\mathrm{D}_{2} \mathrm{O}$ (heavy water) to the composition. Methyl groups in the citric acid composition and in the obtained esters are represented by tremors at 2.45 and $2.70 \mathrm{ppm}$. The tremors coming from 


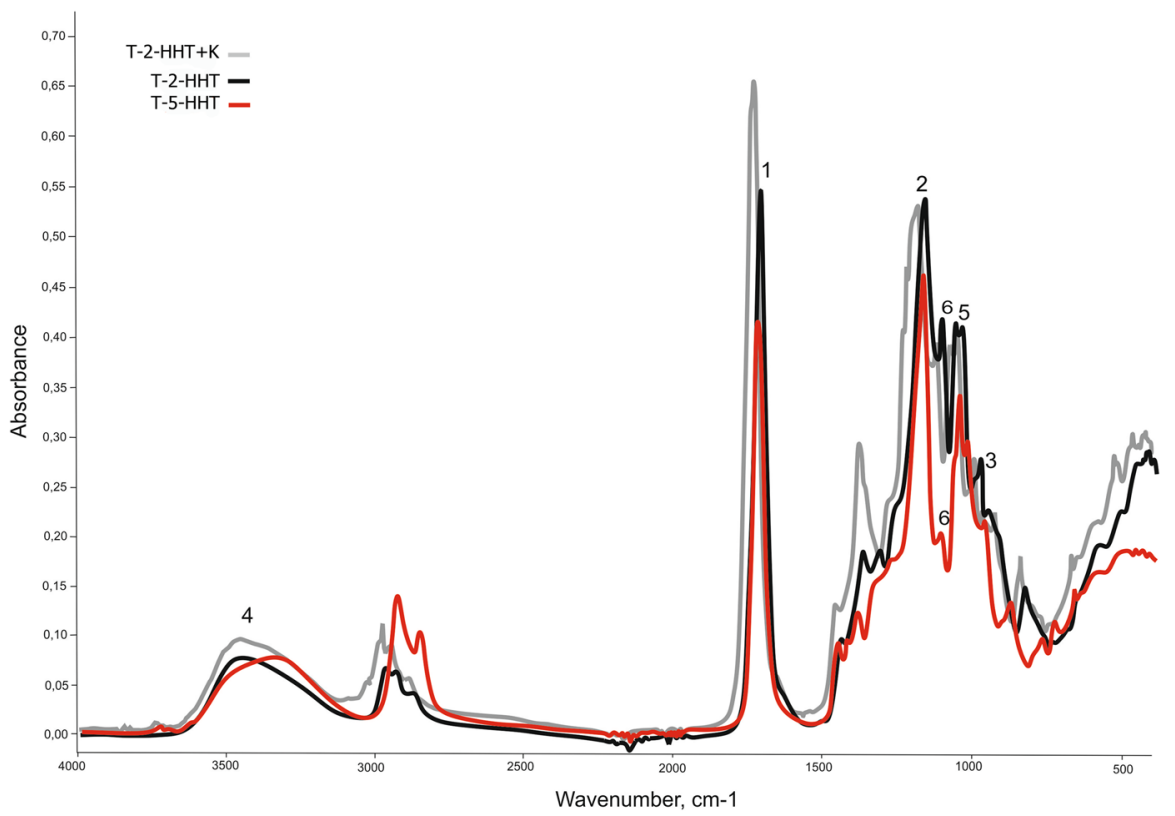

Fig. 1 IR of T-2-HHT + K, T-2-HHT and T-5-HHT: 1 C=O, 2 C-O, 3 OH, 4 OH, 5 C-O-C, 6 C-O-C

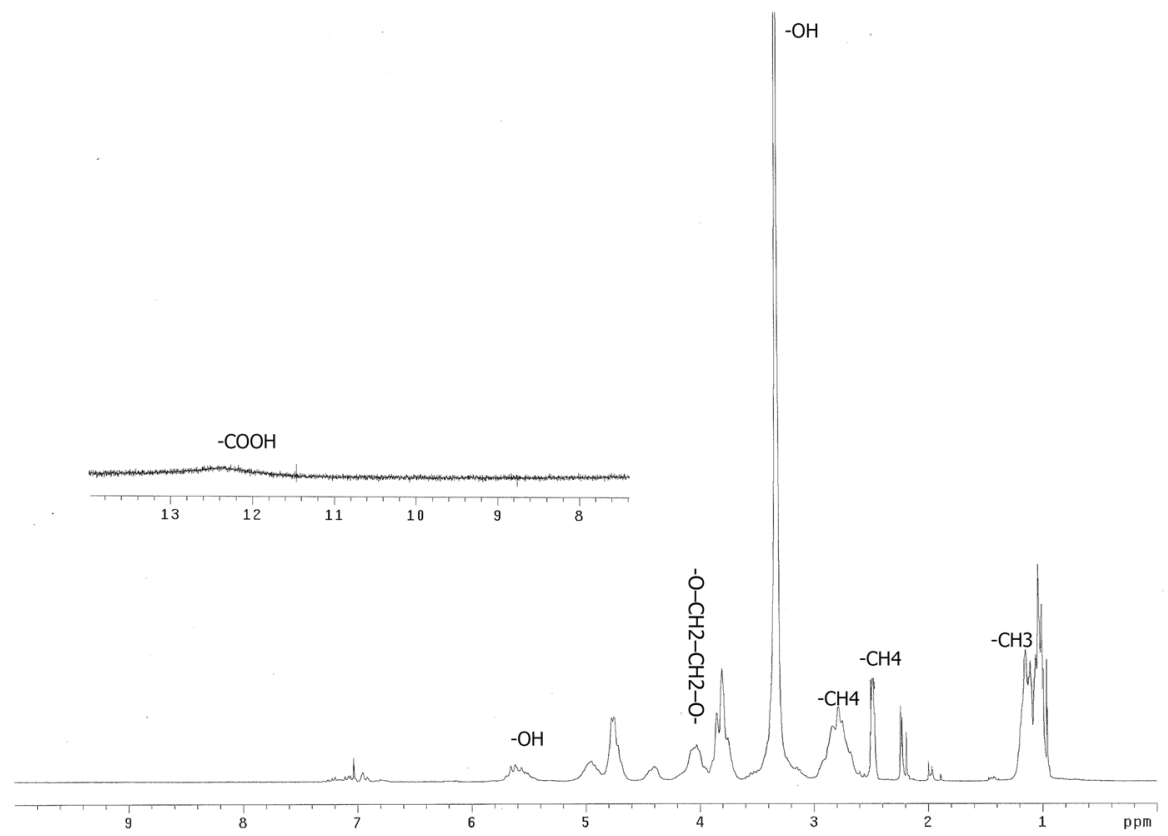

Fig. 2 HNMR of T-2-HHT + K 
methyl group protons present in $-\mathrm{O}-\mathrm{CH}_{2}-\mathrm{CH}_{2}-\mathrm{O}-$ bridges, created during stepgrowth polymerization, are present at the $4.2 \mathrm{ppm}$ chemical shift. Whereas, the tremor of the methyl group directly connected with hydroxyl group has $3.3 \mathrm{ppm}$ shift. The tremor at $1.1 \mathrm{ppm}$ indicates the presence of $-\mathrm{CH}_{3}$ group (for T-2$\mathrm{HHT}+\mathrm{K}$ and T-2-HHT $+\mathrm{K}$ polyols, originating from butane-1.2-diol).

A structural dependency (structural equation) of the obtained polyols on the reaction time was observed. The synthesis time for the polyol with the shortest chain (T-2-HHT) was $6.5 \mathrm{~h}$, for T-5-HHT-8.5 h, and for the polyol (T-2-HHT $+\mathrm{K}$ ) with the longest chain, the synthesis time was the longest and equaled $9.5 \mathrm{~h}$.

Water, reacting with the polyisocyanate, has a significant influence on the foaming process. That is why it is important to know the amount of water in the raw materials in the foaming process. The examination has determined that the amount of water below $1.0 \%$ in the processed raw material will not interrupt the polyurethane foams' production process and does not have to be included in the recipe. With regard to T-2-HHT, where the water amount was $1.2 \%$, and to T-2HHT $+\mathrm{K}$, with $3.2 \%$ of water, the amount of water used in the recipe had to be lowered by the amount of water already present in those compounds.

Also, the $\mathrm{pH}$ value of obtained compounds is close to the range defined by the $\mathrm{pH}$ of standard polyols and is from 2.2 (T-2-HHT $+\mathrm{K}$ compound) to 5.5 (T-2-HHT compound), that is why there is no need to expect great differences in the process of obtaining rigid PUR foams containing various amounts of citrates, which was added instead of the commercial Rocopol RF 551 (Table 2). The remaining two are liquids with straw-yellow (T-2-HHT $+\mathrm{K}$ ) or light-yellow (T-5-HHT) color. The color is a significant factor for PUR processors and for the creators of PUR systems. Colorless (translucent) polyols are the most desirable ones. The glycol used in the synthesis of new compounds influences their color. The only limitation is high viscosity of compounds to polyurethane foams. Viscosity of T-2-HHT could not be measured in $25{ }^{\circ} \mathrm{C}$ temperature. To lower the viscosity, the product was heated to $55^{\circ} \mathrm{C}$, the polyol premix was added and thoroughly mixed. The viscosity of the obtained liquid compounds (T-2-HHT $+\mathrm{K}$ and T-5-HHT) is similar to the viscosity which should be characteristic for raw materials used in standard equipment for PUR processing available on the market, i.e., $15,000 \mathrm{mPa}$ s. They were characterized by the density $1.2 \mathrm{~g} / \mathrm{cm}^{3}\left(\mathrm{~T}-2-\mathrm{HHT}+\mathrm{K}\right.$ ) and $1.053 \mathrm{~g} / \mathrm{cm}^{3}$ (T-5-HHT) (Table 2). Study results of the properties of newly obtained compounds prove, that the density does not prevent it from being used in appliances for synthesizing rigid PUR-PIR foam. They also had a wide range of viscosity, depending on the glycol used for their synthesis, in the range from $3972 \mathrm{mPa}$ s (T-2-HHT $+\mathrm{K}$, synthesized using propane-1.2-diol) to $10,364 \mathrm{mPa} s$ (T-5-HHT, synthesized using propane-1.5-diol). It often happens that the raw materials provided for polyurethanes can be further processed outside of the place where they were synthesized, that is why they should have a specific level of durability during transport or storage. Therefore, it is important to determine their viscosity.

The results from the examination of dissolvability of the obtained compounds in solvents commonly used in the production of PUR foams ( $N, N^{\prime}$-dimethylformamide, toluene, ethyl acetate, ethanol, cyclohexane) and in polyols (Rokopol RF 551, Rokopol RF 55) led to positive conclusions. 
The course of the process temperature inside the foam was measured after $91 \mathrm{~min}$ from the foam rising moment. For serie 16 of foam in 12th to 13 th $\mathrm{min}$, the highest peak of temperatures has been observed (ca. $126{ }^{\circ} \mathrm{C}$ for $\mathrm{W}$ foam, $139{ }^{\circ} \mathrm{C}$ for 16.5 and $145{ }^{\circ} \mathrm{C}$ for 16.1) (Fig. 3). After that time, temperature decrease can be observed. The course of the curves was similar for all foams and does not depend on the amount and type of obtained citrates.
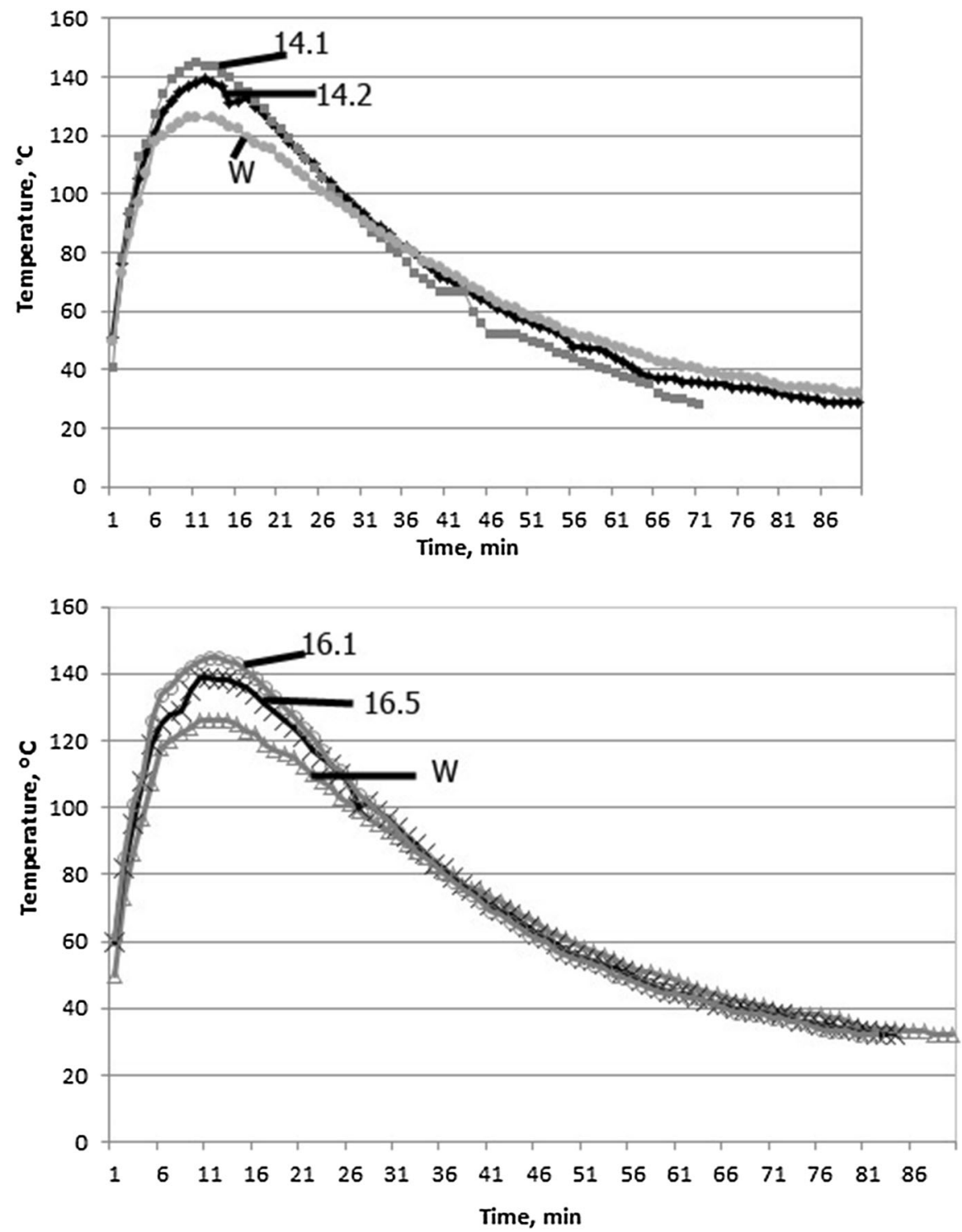

Fig. 3 Temperature changes inside the example foams in the first $90 \mathrm{~min}$ : $W$ reference foam, 16.1 foam F16.1 containing $0.1 \mathrm{R}$ of T-5-HHT, 16.5 foam F16.5 containing 0.5 R of T-5-HHT, 14.1 foam F14.1 containing $0.1 \mathrm{R}$ of $\mathrm{T}-2-\mathrm{HHT}+\mathrm{K}, 14.2$ foam F14.2 containing $0.2 \mathrm{R}$ of T-2-HHT $+\mathrm{K}$ 
IR analysis of foams (Fig. 4) showed presence of isocyanurate bond $\left(1736 \mathrm{~cm}^{-1}\right)$ and urethane bond (2969-2915 $\mathrm{cm}^{-1}$ ) in foams. Moreover, hydroxyl group OH was observed within the range of $3136-3360 \mathrm{~cm}^{-1}$.

The citrates have an influence on foam processing parameters prolongation (Table 3). Start time lengthened from $15 \mathrm{~s}$ (W foam) to $60 \mathrm{~s}$ (14.4 foam), growth time lengthened from $30 \mathrm{~s}(\mathrm{~W})$ to $301 \mathrm{~s}(14.4)$ and gelation time lengthened from $27 \mathrm{~s}(\mathrm{~W})$ to $187 \mathrm{~s}$ (14.4). It is caused by increasing viscosity of the polyol premix added to the composition of the foam.

The examined foams practically did not change their dimensions, volume or mass after thermostating for $48 \mathrm{~h}$ in $120{ }^{\circ} \mathrm{C}$ temperature (Table 4).

By observing the foam cells in SEM picture (Fig. 5) taken according to their growth direction, "crumbling" of cell walls can be seen in the foam. By comparing the foams' structure according to their growth and opposite their growth (Fig. 6), it is hard to find any drastic changes in cell shapes. One thing that can be observed is the fact that foams with higher amount of E16 have slightly more spherical shape in comparison to those with lower amounts of E16 compound. Such shapes are contributed to the prolonged processing times during foam syntheses. On the pictures (Figs. 5, 6) there is a visible deformity and cracking of the cell walls of foams containing 0.4 and $0.5 \mathrm{R}$ of the T-5-HHT. It is indicated by the lack of thermal stability of the foam product (Table 4). In comparison to the foam based on the petrochemical polyol (Rokopol, R foam) and the T-2-HHT and T-2-HHT $+\mathrm{K}$ polyols, the deformities and cracking do not occur. The structure of foams obtained with T-2-HHT and T-2-HHT $+\mathrm{K}$ (from $0.1 \mathrm{R}$ to $0.4 \mathrm{R}$ ) and foams obtained with T-2-HHT (from $0.1 \mathrm{R}$ to $0.3 \mathrm{R}$ ) does not deviate from the structure of foams produced with the use of, e.g., Alfapor 551 or vegetable oil [18].

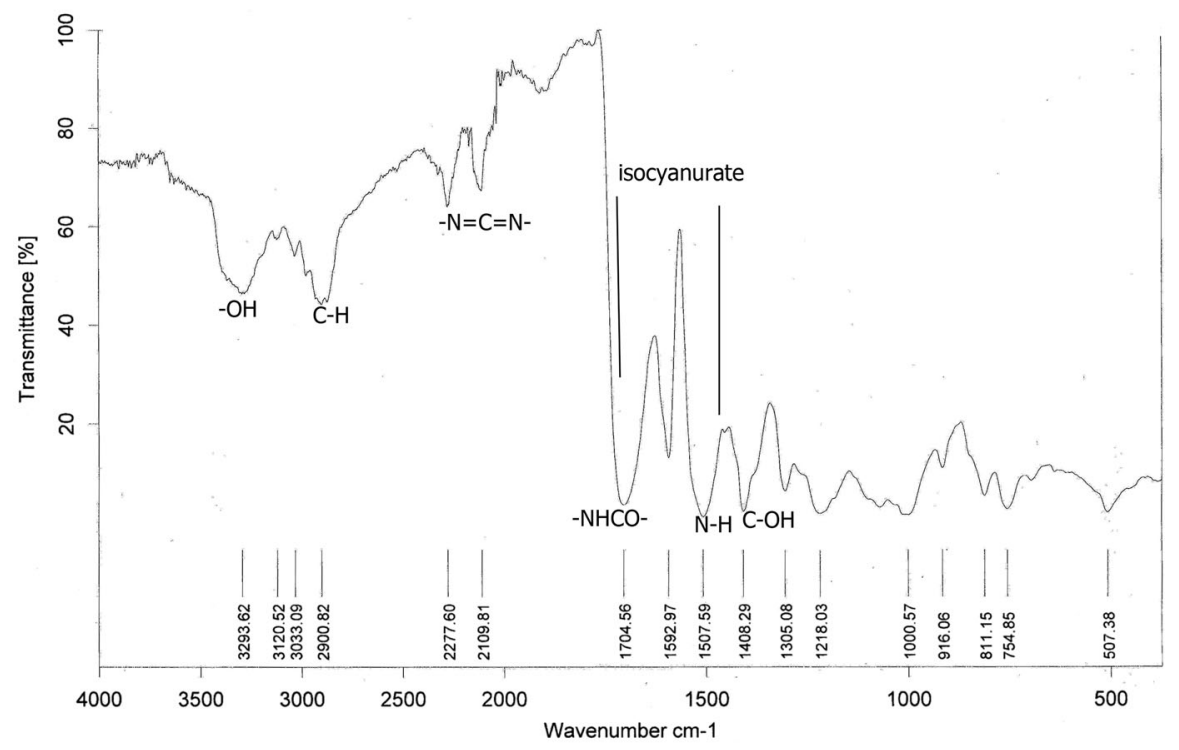

Fig. 4 IR of foam 
Table 3 Foam processing parameters

\begin{tabular}{llll}
\hline Start time (s) & Start time (s) & Growth time (s) & Gelation time (s) \\
\hline W & 10 & 30 & 27 \\
P14.1 & 15 & 45 & 44 \\
P14.2 & 17 & 95 & 90 \\
P14.3 & 30 & 181 & 187 \\
P14.4 & 60 & 301 & 310 \\
P15.1 & 11 & 35 & 29 \\
P15.2 & 13 & 40 & 39 \\
P15.3 & 15 & 56 & 55 \\
P15.4 & 18 & 72 & 65 \\
P16.1 & 17 & 44 & 46 \\
P16.2 & 19 & 48 & 44 \\
P16.3 & 20 & 53 & 65 \\
P16.4 & 21 & 60 & 82 \\
P16.5 & 25 & 61 & 92
\end{tabular}

Table 4 The examination of changes in foams' linear dimensions, volume and mass after $48 \mathrm{~h}$ of thermostating in $120^{\circ} \mathrm{C}$ temperature

\begin{tabular}{lllll}
\hline Foam name & $\begin{array}{l}\text { Sample's dimension } \\
\text { changes according } \\
\text { to the growth } \\
\text { direction } \Delta \mathrm{l}_{\mathrm{z}}(\%)\end{array}$ & $\begin{array}{l}\text { Sample's dimension } \\
\text { changes opposite } \\
\text { to the growth } \\
\text { direction } \Delta \mathrm{l}_{\mathrm{z}}(\%)\end{array}$ & $\begin{array}{l}\text { Volume change, } \\
\Delta \mathrm{V}(\%)\end{array}$ & $\begin{array}{l}\text { Mass change, } \\
\Delta \mathrm{m}(\%)\end{array}$ \\
\hline $\mathrm{W}$ & 0 & 0 & 0 & 0 \\
$\mathrm{P} 14.1$ & 0 & -0.0019 & 1.9 & 0.35 \\
P14.2 & 0 & -0.0090 & 0 & 0.9 \\
P14.3 & -0.98 & -0.0019 & 1 & 0.60 \\
P14.4 & -1 & -0.0099 & 1.9 & 0.87 \\
P15.1 & 0 & 0 & 1.9 & 0.35 \\
P15.2 & -1.9 & -0.0059 & 1.9 & 0.17 \\
P15.3 & 0 & -0.0019 & 1 & 0 \\
P15.4 & 0 & 0 & 1.9 & 0 \\
P16.1 & 0 & 0.011 & 1.2 & 0 \\
P16.2 & -1.9 & 0 & 1.9 & 0.17 \\
P16.3 & -1.1 & -1.1 & -0.9 & 1.1 \\
P16.4 & -0.17 & 0.05 & 2.1 & 1.2 \\
P16.5 & 0.02 & 2.1 & 1.08 & 1.4 \\
\hline & & & & 0 \\
\hline
\end{tabular}

The density of PUR-PIR foams depends on the type of ester compound (E14, E15 czy E16) used in the premix (Table 5). The density of F14 foams practically does not depend on the amount of E14 compound and varies between 35.1 and $43.5 \mathrm{~kg}$ / $\mathrm{m}^{3}$. For the F15 foams, the density is higher (in comparison to F14) and increases along with the higher amount of E15 in the foam, from $44.3 \mathrm{~kg} / \mathrm{m}^{3}$ (F15.1) to $48.0 \mathrm{~kg} / \mathrm{m}^{3}$ (F15.5). F15.3 is an exception. However, for the F16 foam series, the 

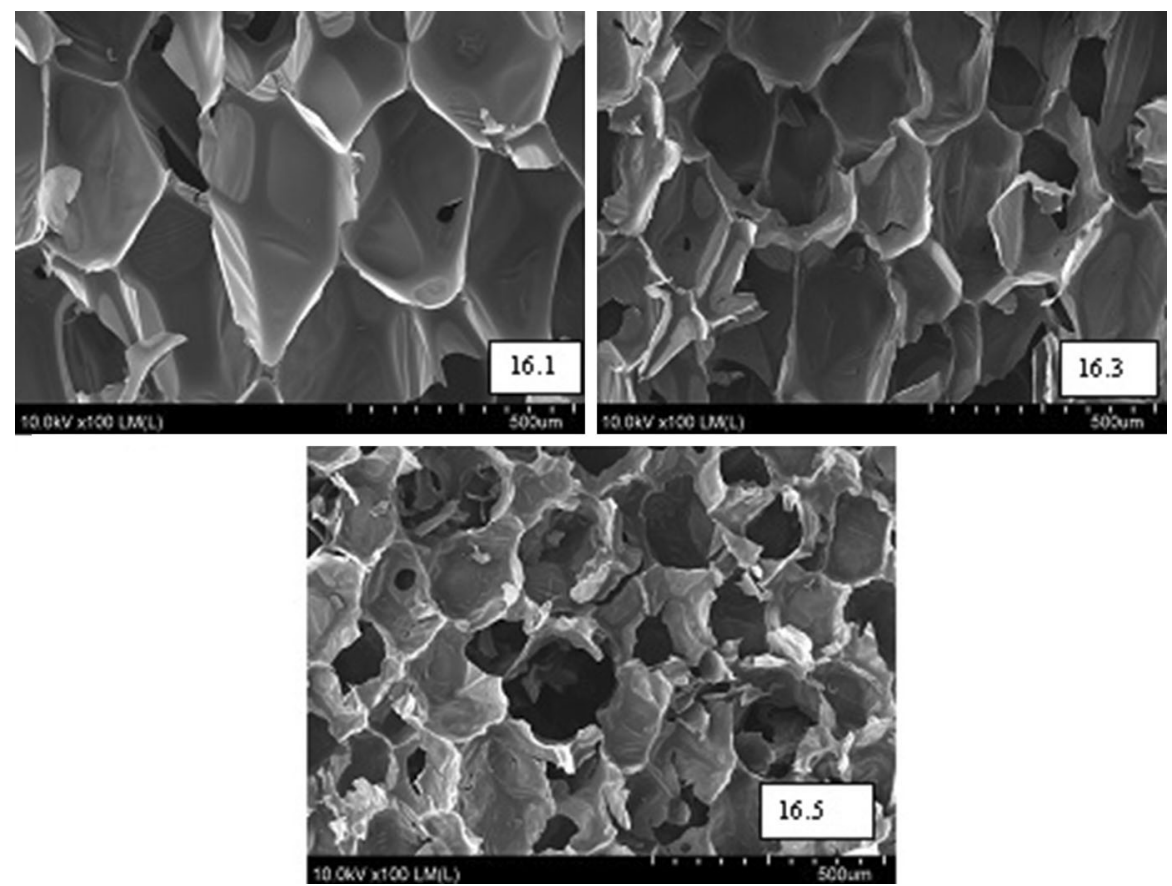

Fig. 5 SEM pictures of 16.3, 16.4 and 16.5 foams' cross-sections (according to the growth direction): 16.1 foam F16.1 containing 0.1 R of T-5-HHT, 16.3 foam F16.3 containing 0.3 R of T-5-HHT, 16.5 foam F16.5 containing $0.5 \mathrm{R}$ of $\mathrm{T}-5-\mathrm{HHT}$
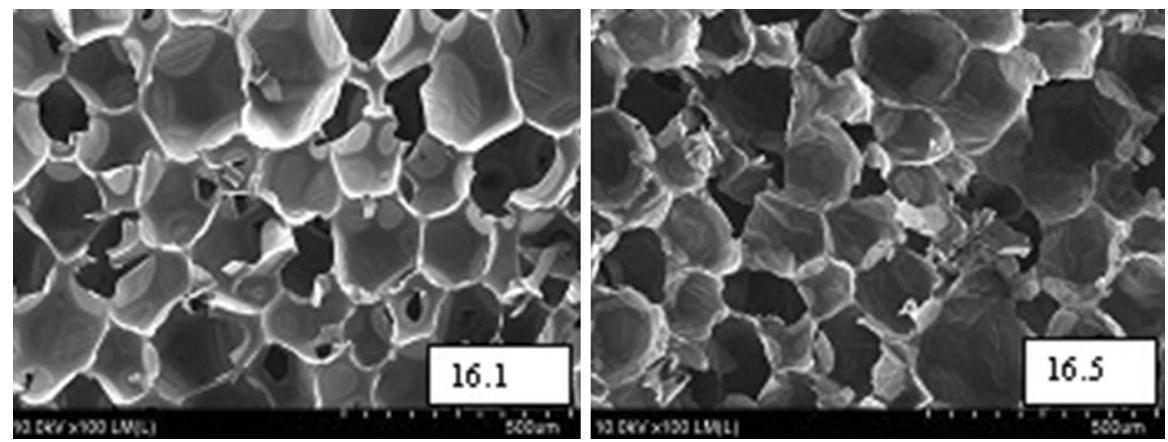

Fig. 6 SEM pictures of 16.3 and 16.5 foams' cross-sections (opposite the growth direction): 16.3 foam F16.3 containing $0.3 \mathrm{R}$ of T-5-HHT, 16.5 foam F16.5 containing $0.5 \mathrm{R}$ of T-5-HHT

density is the highest (in comparison to F14 and F15) and increases along with the amount of ester compound in the foam, from $37.7 \mathrm{~kg} / \mathrm{m}^{3}$ (F16.1) to $65.1 \mathrm{~kg} / \mathrm{m}^{3}$ (F16.4).

Depending on the amount of closed cells in the foams, which increases along with the amount of ester compound in the foams, water absorption changes (Fig. 7). 
Table 5 Foams' physicomechanical properties

\begin{tabular}{lllc}
\hline Foam & Density $\left(\mathrm{kg} / \mathrm{m}^{3}\right)$ & Softening point $\left({ }^{\circ} \mathrm{C}\right)$ & Brittleness $(\%)$ \\
\hline $\mathrm{W}$ & 37.5 & 230 & 41.1 \\
F14.1 & 43.5 & 233 & 22.3 \\
F14.2 & 35.1 & 204 & 10.9 \\
F14.3 & 36.3 & 201 & 8.7 \\
F14.4 & 35.3 & 190 & 6.9 \\
F15.1 & 44.3 & 220 & 25.2 \\
F15.2 & 46.3 & 212 & 25.0 \\
F15.3 & 43.5 & 205 & 25.8 \\
F15.4 & 48.0 & 204 & 7.1 \\
F16.1 & 37.5 & 212 & 23.5 \\
F16.2 & 46.8 & 208 & 22.4 \\
F16.3 & 46.9 & 194 & 21.7 \\
F16.4 & 65.1 & 172 & 20.4 \\
F16.5 & 89.2 & 169 & 17.3
\end{tabular}

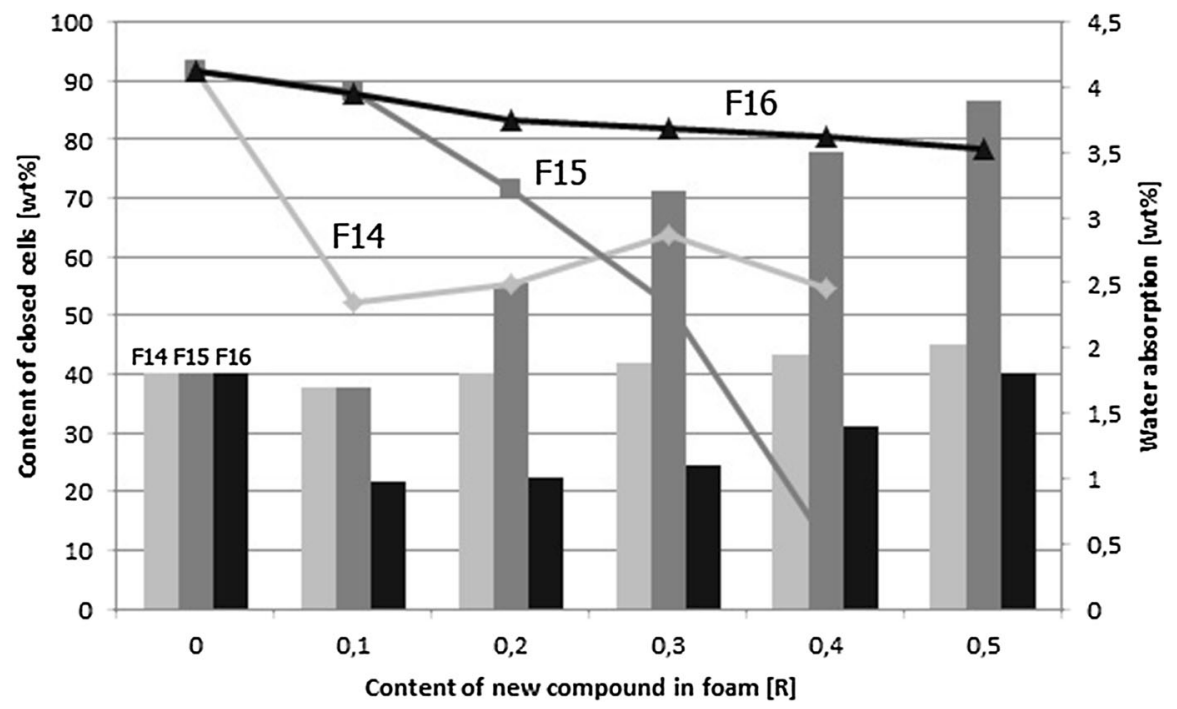

Fig. 7 Dependence of the content of new compounds in foams on the content of closed cells (and water absorption): T-5-HHT product in foam; F14 foam F14 containing T-2-HHT + K, F15 foam F15 containing T-2-HHT, F16 foam F16 containing T-5-HHT

Small changes in water absorption can be seen for F14 and F16 foam series (about $2 \%$ ). The lack of major changes in water absorption is dependent on the minor changes in the content of closed cells. However, for F15 foam series, a significant decrease in water absorption can be seen, from $1.8 \%$ (W foam) to $3.9 \%$ (F15.5 foam). Such decrease is caused by a rather high increase in the content of closed cells in F15 foam series from about $40 \%$ (W) to $95 \%$ (F15.5). 


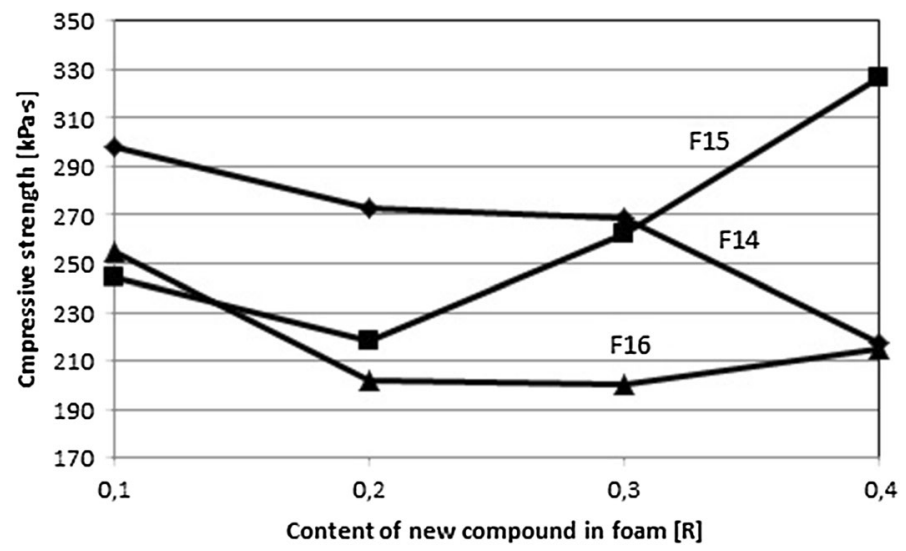

Fig. 8 Dependence of compressive strength on contents of T-2-HHT + K, T-2-HHT, T-5-HHT product in foam: F14 foam F14 containing T-2-HHT + K, F15 foam F15 containing T-2-HHT, F16 foam F16 containing T-5-HHT

Table 6 Thermal changes of PUR-PIR foams containing $0.3 \mathrm{R}$ of the polyols

\begin{tabular}{|c|c|c|c|c|c|c|c|c|}
\hline \multirow[t]{2}{*}{ Foam } & \multicolumn{4}{|l|}{ Pik $T_{\mathrm{a}}$} & \multicolumn{4}{|l|}{ Pik $T_{\mathrm{b}}$} \\
\hline & $T_{0}\left({ }^{\circ} \mathrm{C}\right)$ & $T_{\max }\left({ }^{\circ} \mathrm{C}\right)$ & $T_{\mathrm{k}}\left({ }^{\circ} \mathrm{C}\right)$ & $H(\mathrm{~J} / \mathrm{g})$ & $T_{0}\left({ }^{\circ} \mathrm{C}\right)$ & $T_{\max }\left({ }^{\circ} \mathrm{C}\right)$ & $T_{\mathrm{k}}\left({ }^{\circ} \mathrm{C}\right)$ & $H(\mathrm{~J} / \mathrm{g})$ \\
\hline 14.3 & 35.5 & 80.9 & 137.5 & 29.38 & 211.2 & 261.9 & 279.8 & 19.28 \\
\hline 15.3 & 32.8 & 80.5 & 120.1 & 25.44 & 212.7 & 260.9 & 279.2 & 25.74 \\
\hline 16.3 & 33.8 & 75.8 & 124.8 & 28.80 & 218.0 & 264.0 & 276.3 & 8.50 \\
\hline \multirow[t]{2}{*}{ Foam } & \multicolumn{4}{|l|}{ Pik $T_{\mathrm{c}}$} & \multicolumn{4}{|l|}{ Pik $T_{\mathrm{x}}$} \\
\hline & $T_{0}\left({ }^{\circ} \mathrm{C}\right)$ & $T_{\max }\left({ }^{\circ} \mathrm{C}\right)$ & $T_{\mathrm{k}}\left({ }^{\circ} \mathrm{C}\right)$ & $H(\mathrm{~J} / \mathrm{g})$ & $T_{0}\left({ }^{\circ} \mathrm{C}\right)$ & $T_{\max }\left({ }^{\circ} \mathrm{C}\right)$ & $T_{\mathrm{k}}\left({ }^{\circ} \mathrm{C}\right)$ & $H(\mathrm{~J} / \mathrm{g})$ \\
\hline 14.3 & 313.1 & 325.8 & 349.5 & 21.67 & 279.8 & 294.2 & 312.0 & 13.91 \\
\hline 15.3 & 314.3 & 326.9 & 349.9 & 18.65 & 279.2 & 294.5 & 312.5 & 18.65 \\
\hline 16.3 & 314.6 & 328.1 & 370.0 & 31.44 & 276.3 & 291.0 & 300.0 & 16.40 \\
\hline
\end{tabular}

The addition of new E15 compound to the PUR-PIR foams affected, among others, the foams' compressive strength (Fig. 8). It was increasing from $185 \mathrm{kPa} \mathrm{s}$ (W foam containing $0 \mathrm{R}$ of the E15) to $327 \mathrm{kPa}$ s (15.4 foam containing $0.4 \mathrm{R}$ of the E15). This was caused by the increasing foam density. The compressive strength curves for F14 and F16 foams behave differently than the F15 foam. After adding $0.1 \mathrm{R}$ of each of the compounds, an increase in the compressive strength to about $240 \mathrm{kPa} \mathrm{s}$ is visible in comparison to the $\mathrm{W}$ foam (182 $\mathrm{kPa} \mathrm{s})$. After that, the value decreases to about $210 \mathrm{kPa} \mathrm{s}$ and the strength values stabilize.

Also, a slight decrease in the foam softening temperature could be observed (Table 6), from $230{ }^{\circ} \mathrm{C}(\mathrm{W})$ to $169{ }^{\circ} \mathrm{C}(\mathrm{F} 16.5)$. 
Fig. 9 DSC of foams 14.3, 15.3 and 16.3
Sample: 14.3
Size: $3.0000 \mathrm{~m}$

Size: $3.0000 \mathrm{mg}$
Method: Heat Cool/Heal

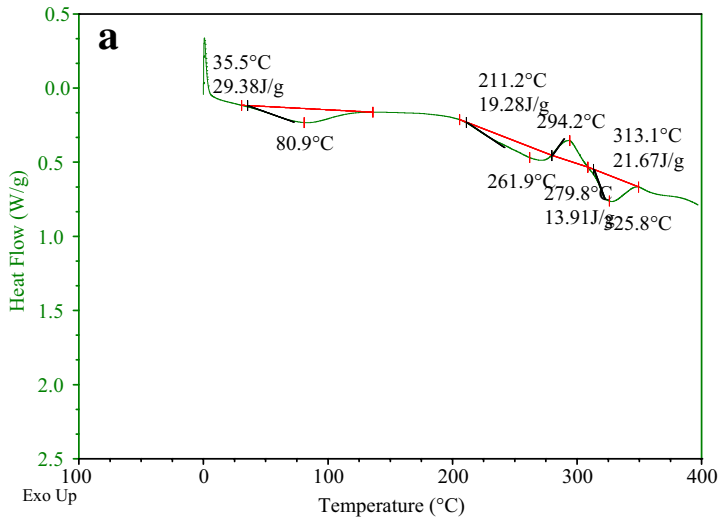

Sample: 15.3

Size: $2.8000 \mathrm{mg}$
Method: Heat/Cool/He

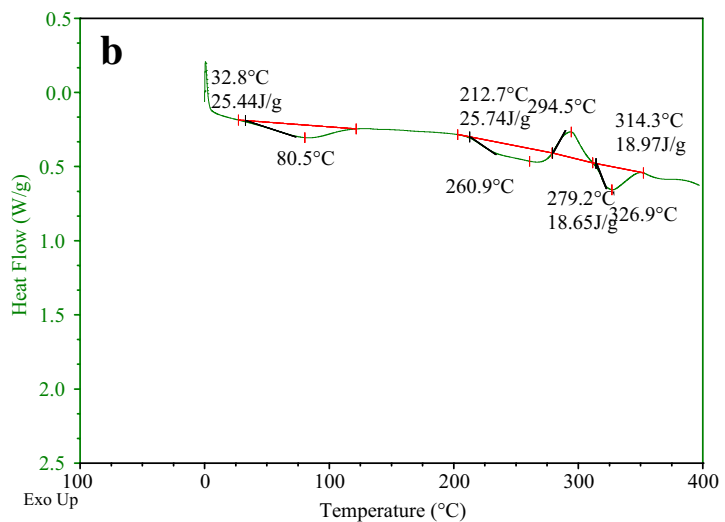

Sample: 16.3
Size: $2.2000 \mathrm{mg}$

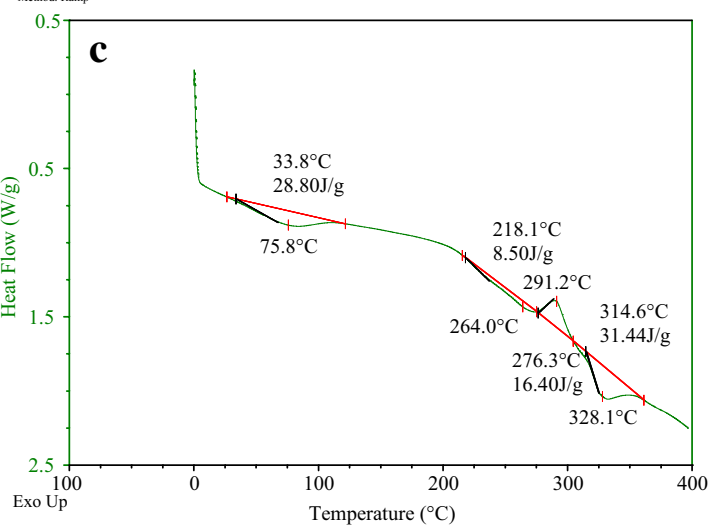


The foam brittleness decreased significantly as well, from $41.1 \%$ (W) to about $7 \%$ (F14.4 and F15.4) and to 17.3 (F16.5). The brittleness decrease is caused by the increase in flexible bonds in the foams' structure due to the higher amount of ester compounds.

Thermograms of selected foams containing average amount of the obtained polyols, are represented in Fig. 9. For each foam (14.3, 15.3 and 16.3), three endothermic and one exothermic changes were observed. The beginning of the change at different peaks was marked as $T_{0}$, the end as $T_{\mathrm{k}}$, and the maximum value of the change at a given peak as $T_{\max }$. The first change (representing $T_{\mathrm{a}}$ peak) begins for the examined foams at the following temperatures: $32.8{ }^{\circ} \mathrm{C}$ (for 15.3 foam), $33.8{ }^{\circ} \mathrm{C}$ (16.3 foam) and $33.5^{\circ} \mathrm{C}$ (14.3 foam). The change at this peak lasts until reaching the following $T_{\mathrm{k}}$ temperatures: $12.1{ }^{\circ} \mathrm{C}$ (15.3), $124.8{ }^{\circ} \mathrm{C}$ (16.3) and $137.5^{\circ} \mathrm{C}(14.3)$. This change is presumably related to the porophor diffusion from the foams. The enthalpy for this change equals almost $30 \mathrm{~J} / \mathrm{g}$. The next endothermic change (at $T_{\mathrm{b}}$ peak) starts at $211-218{ }^{\circ} \mathrm{C}$ temperature and ends at around $280{ }^{\circ} \mathrm{C}$ temperature. In this temperature range, reactions related to the decompositions of the following bonds are observed: urethane, urea (with the recreation of isocyanates, diols and micromolecular compounds, e.g., amines), ether and polyoxypropylene groups present in polyols. The third change (at $T_{\mathrm{c}}$ peak) starts at around $314{ }^{\circ} \mathrm{C}$ temperature and ends at $350{ }^{\circ} \mathrm{C}$ (for 14.3 and 15.3 foams) and $370{ }^{\circ} \mathrm{C}$ (for 16.3 foam). At those temperatures, carbodiimides and isocyanurates are decomposed. One endoenergetic change at the temperature range of $T_{0}=291-294.5{ }^{\circ} \mathrm{C}$ to $T_{\mathrm{k}}=300-312{ }^{\circ} \mathrm{C}$ was observed for each foam. The presence of this change can be justified by the reactions between micromolecular compounds, diols and isocyanates created during the exoenergetic change (at $T_{\mathrm{b}}$ peak).

\section{Conclusion}

Obtained new compounds tris(2-hydroxypropyl)-2-hydroxypropane-1.2.3-tricarboxylate (T-2-HHT $+\mathrm{K}$ and T-2-HHT) and tris(5-hydroxypentyl)-2-hydroxypropane-1.2.3-tricarboxylate (T-5-HHT) with the participation of citric acid and butane-1.2.-diol or pentane-1.5-diol. They were added to PUR-PIR foams in premix polyol in amount of $0.1 \mathrm{R}-0.5 \mathrm{R}$ replace industrial Rocopol RF 551 (0 R-0.5 R). The only limitation is high viscosity of (T-2HHT), which could not be measured in $25{ }^{\circ} \mathrm{C}$ temperature. To lower the viscosity, the product was heated to $55^{\circ} \mathrm{C}$. Obtained three series of five (or four) rigid PUR-PIR foams each. The addition of T-2-HHT + K, T-2-HHT and T-5-HHT to the foams affects the foams' density and foaming parameters. It does not affect softening point (only slightly decreases). It increases compressive strength of obtained foams.

The additions of new T-2-HHT $+\mathrm{K}, \mathrm{T}-2-\mathrm{HHT}$ and T-5-HHT polyols produced from a cheap material such as citric acid, resulted in the increase of foams' crosslinking. As a consequence, the compressive strength of the foam increased in relation to the foam obtained based on the petrochemical material (Rokopol). The produced foams can be used as a protective material during the shipment of electronic devices, household appliances, white goods, or as packaging material. 
Open Access This article is distributed under the terms of the Creative Commons Attribution 4.0 International License (http://creativecommons.org/licenses/by/4.0/), which permits unrestricted use, distribution, and reproduction in any medium, provided you give appropriate credit to the original author(s) and the source, provide a link to the Creative Commons license, and indicate if changes were made.

\section{References}

1. Fink JK (2005) Reactive polymers fundamentals and applications. William Andrew, Inc., Norwich, pp 84-91

2. Czupryński B (2004) Chemistry and polyurethane technology issues (in polish). Akademia Bydgoska, Bydgoszcz, pp 44-62

3. Landrock AH (ed.) (1995) Handbook of plastic foams. Types, properties, manufacture and application. Noyes Publications, Mill Road, Park Ride, pp 21-23

4. Wirpsza Z (1991) Poliuretany. Chemia, technologia, zastosowanie. WNT Warszawa, pp 46-58

5. Lubczak J (2011) Polyhydroxyalkyl derivatives and polyetherols obtained from azacyclic compounds. Part I. Reactions with oxiranes. Polimery 56(5):360-368

6. Lubczak J (2011) Polyhydroxyalkyl derivatives and polyetherols obtained from azacyclic compounds. Part II. Reactions with formaldehyde and alkylene carbonates. Polimery 56(6):452-460

7. Lubczak R (2011) Synthesis of oligoetherols with a carbazole ring and an azo group. Polimery 56(2):146-150

8. Paciorek-Sadowska J, Czupryński B, Liszkowska J, Jaskółowski W (2010) Nowy poliol boroorganiczny do produkcji sztywnych pianek poliuretanowo-poliizocyjanurowych, Cz. II. Otrzymywanie sztywnych pianek poliuretanowo-poliizocyjanurowych $\mathrm{z}$ zastosowaniem nowego poliolu boroorganicznego. Polimery 55(2):99-105

9. Paciorek-Sadowska J, Czupryński B, Liszkowska J (2010) New polyol for production of rigid polyurethane-polyisocyanurate foams. Part 2. Preparation of rigid polyurethane-polyisocyanurate foams with the new polyol. J Polym Eng 30(3-4):229-244

10. Brzozowski Z, Kijeńska D, Jóźwik M (2007) Przedmieszka poliolowa do wytwarzania ekologicznej sztywnej pianki poliuretanowej o zmniejszonej palności i zastosowanie przedmieszki poliolowej. Patent PL195392

11. Zielecka M, Bujnowska E, Jeziórska R, Cyruchin K, Pytel A, Wenda M (2012). Sposób wytwarzania nanonapełniacza zmniejszającego palność polimerów. Patent P-391081

12. Zia KM, Bhatti HN, Bhatti IA (2007) Methods for polyurethane and polyurethane composites, recycling and recovery: a review. React Funct Polym. 67:675-692

13. Pielichowski J, Prociak A, Michałowski S, Bogdał D (2010) Możliwości wykorzystania odpadów wybranych polimerów w produkcji spienionych tworzyw poliuretanowych. Polimery 55(10):757-764

14. Czupryński B, Liszkowska J, Paciorek-Sadowska J (2010) Glycolysis of rigid polyurethane-polyisocyanurate foams. Polimery 55(4):314-319

15. Czupryński B, Liszkowska J, Paciorek-Sadowska J (2012) Glycolysis of the rigid PUR-PIR foam modified with starch. J Appl Polym Sci 126:E44-E53

16. Czupryński B, Liszkowska J, Paciorek-Sadowska J, Lewandowski R (2010) Właściwości sztywnych pianek poliuretanowo-poliizocyjanurowych otrzymanych z dodatkiem produktów ich glikolizy. Przem Chem 89(5):734-741

17. Spychaj T, Kacperski M (2007) Reaktywna mieszanina polioli do wytwarzania sztywnej pianki poliuretanowej oraz sztywna piana poliuretanowa. Patent PL93288

18. Prociak A (2008) Poliuretanowe materiały termoizolacyjne nowej generacji, p Wydawnictwo PK, Kraków

19. Prociak A (2008) Heat-insulating properties of rigid polyurethane foams synthesized with use of vegetable oils-based polyols. Polimery 53(3):195-200

20. Prociak A (2007) Properties of NOP modified polyurethane foams. Polyurethane Mag 4:218-224

21. Pawlik H, Prociak A (2011) Modyfikacja polimerów. Stan i perspektywy na rok 2011. Wrocław, Wydawnictwo Tempo s.c, pp 159-162

22. Kurańska M, Prociak A (2012) Porous polyurethane composites with natural fibres. Comp Sci Technol. 72:299-304 
23. Kurańska M, Prociak A (2011) Właściwości termoizolacyjne i mechaniczne spienionych kompozytów poliuretanowych z włóknami konopnymi. Chemik 65(10):1055-1058

24. Soccol CS, Vandenberghe PS, Rodrigues C, Pandey A (2006) New perspectives for citric acid production and application. Food Technol Biotechnol. 44(2):141-149

25. Vandenberghe LPS, Soccol CR, Pandey A, Lebeault JM (1999) Microbial production of citric acid. Braz Arch Biol Technol 42:263-276

26. Grewal HS, Kalra KL (1995) Fungal production of citric acid. Biotechnol Adv 13:209-234

27. Pandey A, Soccol CR, Rodriguez-Leon JA, Nigam P (2001) Production of organic acids by solidstate fermentation. Solid-state fermentation in biotechnology-fundamentals and applications. Asiatech Publishers Inc., New Delhi, pp 113-126

28. Tisserat B, O'kuru RH, Hwang HS, Abdellatif AM, Holser R (2012) Glycerol citrate polyesters produced through heating without catalysis. J Appl Polym Sci 125:3429-3437

29. Holster RA (2008) Thermal analysis of glycerol citrate/starch blends. J Appl Polym Sci 110:1498-1501

30. Liszkowska J, Czupryński B, Paciorek-Sadowska J (2012) Właściwości i budowa poliestroli wytworzonych z kwasu cytrynowego i butanodiolu oraz zsyntezowanych z ich udziałem sztywnych pianek PUR-PIR. Przem Chem 91(10):1000-1006

31. Liszkowska J, Czupryński B, Paciorek-Sadowska J (2013) Recykling sztywnej pianki PUR-PIR z nowym poliolem. Materiały Polimerowe Pomerania-Plast, Międzyzdroje, pp 263-264

32. Zarzyka I (2005) Oligomers with structural elements of imidazolidinetrione obtained from oxamic acid and oxamide: polyurethane foams modified by structural elements of imidazolidinetrione. J Polym Eng 35(1):303-406

33. Liszkowska J, Czupryński B, Paciorek-Sadowska J (2015) Tris(hydroxydiethylene)-2-hydroxypropane-1,2,3-tricarboxylate for rigid PUR-PIR foams. J Polym Eng 35(8):743-751

34. Liszkowska J, Czupryński B, Paciorek-Sadowska J (2013). Use of a new polyol for production of rigid polyurethane-polyisocyanurate foams. Przemysł Chemiczny 92(11):1994-1999

35. Choi SH, Kim DH, Raghu AV, Reddy KR, Lee H-I, Yoon KS, Jeong HM, Kim BK (2012) Properties of graphene/waterborne polyurethane nanocomposites cast from colloidal dispersion mixtures. J Macromol Sci Part B Phys 51:197-207

36. Reddy KR, Raghub AV, Jeongc MH, Siddaramaiahd (2009) Synthesis and characterization of pyridine-based polyurethanes. Des Monom Polym 9(12):109-118

37. Reddy KR, Raghu AV, Jeong HM (2008) Synthesis and characterization of novel polyurethanes based on 4,4'-\{1,4-phenylenebis[methylylidenenitrilo] $\}$ diphenol. Polym Bull 60:609-616 